\title{
Sumbangan Daná Kampanye Pemilu dan Kejahatan Korporasi
}

\author{
M. Arief Amrullah
}

\begin{abstract}
The form of corporate crime is not only in the field of environment pollution, deceive of consummer, unfair trade practices, etc, but also in the field of politics. In this field, it is usually for economic advantage through the campaign fund contributed to the party. In USA, Watergate scandal, for example, it shows the corporate involvement in the general ellections arena, so that in 1971 the USA government legislated a new regulation limiting the sum of comporate contribution to political party.Indonesia, in the face of genertal election 2004, has anticipated it by UUNo. 12 Tahun 2003. However, if we pay close attention to penal policy as regulated in Article 138 section (5) which just regulates capital punishment (imprisonment and fine), while the additional punishment is not regulated in that statute, it is worried that the statute will not be efective to prevent the corporation's violation of the constribution limit tolerated by the statute.The weakness of the formulation policy will influence the interaction perpetuation which benefit each-other between contributor and receiver of contribution. As a consequence, it is difficult to prevent the conspirative connection for each elite group interest.Key words: Campaign contribution, corporate crime.
\end{abstract}

\section{Pendahuluan}

Pada awal studi terhadap white-collar crime perhatian lebih difokuskan pada kejahatan yang dilakukan oleh individu secara rahasia, misalnya seperti penggelapan, dan kurang memperhatikan pada kejahatan korporasi yang dengan kekomplekannya tidak hanya terhadap kejahatan korporasi itu sendiri tapi juga struktur korporasi, akan tetapi dalam perkembangannya telah terjadi perubahan. Ada beberapa alasan terjadinya perubahan penekanan dari kejahatan white-collar secara individu kepada kejahatan korporàsi, yaitu antara lain:

1. Dalam abad ini telah disaksikan ledakan yang luar biasa dalam jumlah dan ukuran korporasi, hal itu menunjukkan bahwa sebenarnya semua kegiatan ekonomi, sosial dan politik sebagian besar dipengaruhi oleh perilaku korporasi.

2. Sekalipun media sedikit memberikan publisitas penuntutan terhadap kejahatan korporasi, bukan berarti tidak ada kasus 
kẹjāihātân kôrpôräsisi:

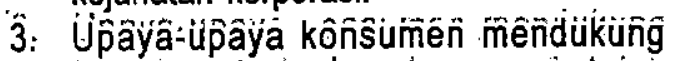

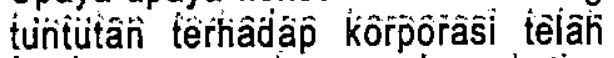

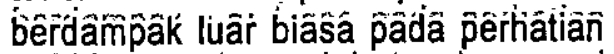

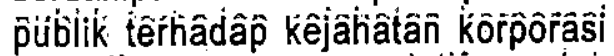

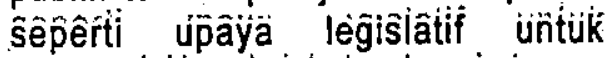

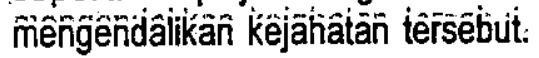

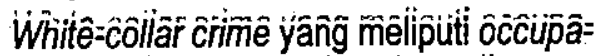

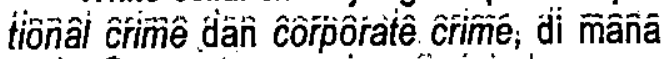

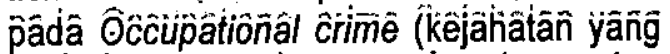

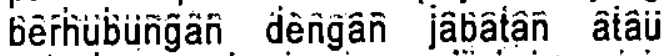

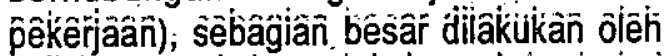

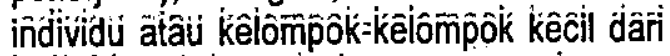

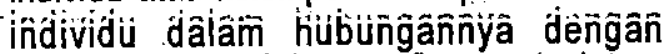

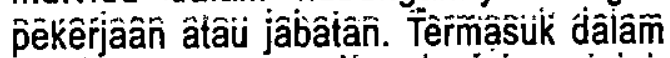

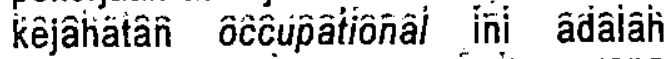

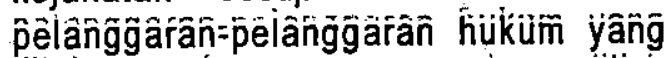

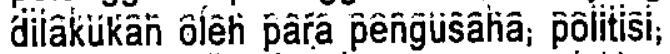

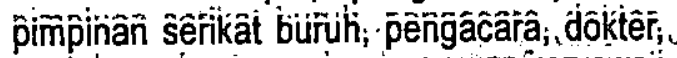

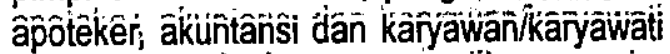

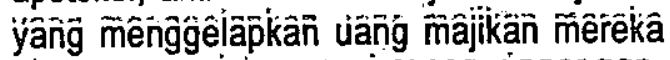

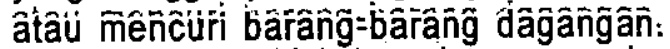

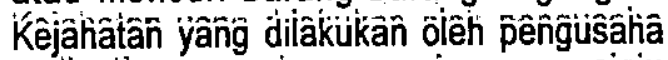

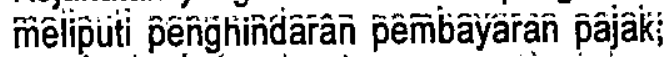

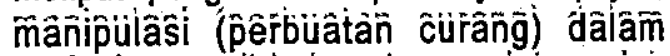

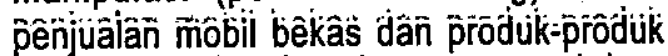

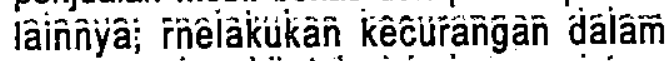

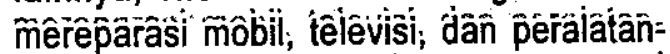

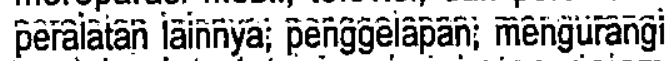

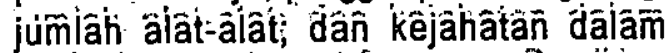

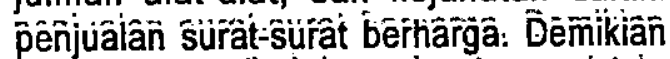

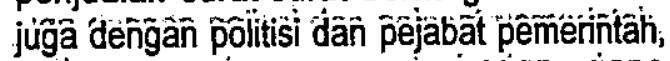

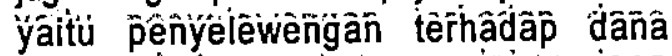

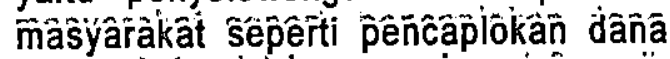

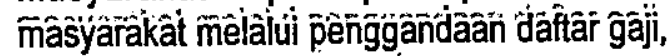

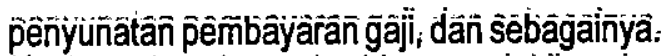

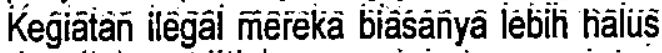

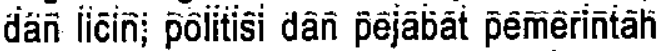

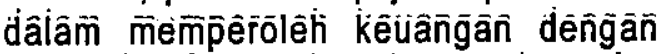

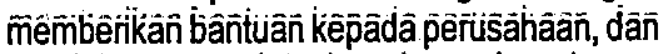

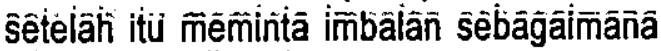

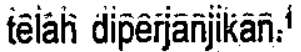

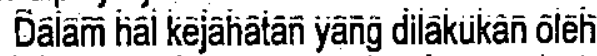

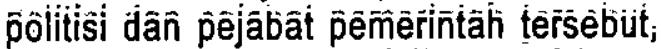

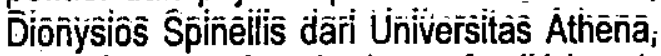

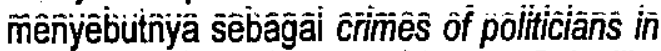

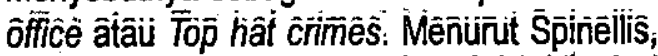

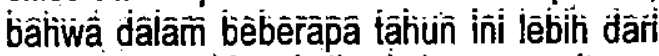

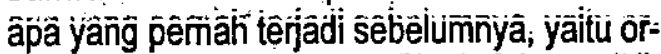

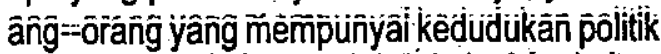

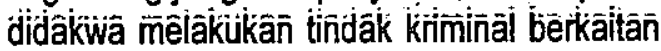

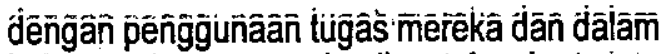

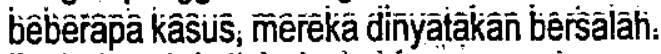

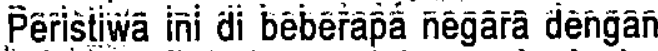

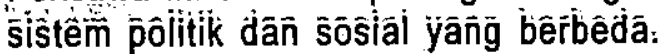

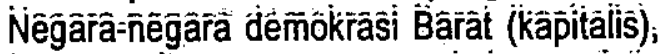

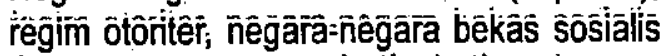

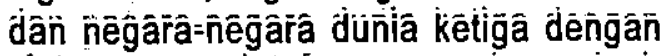

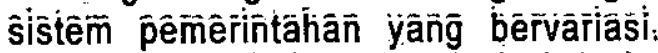

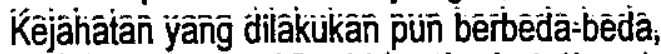

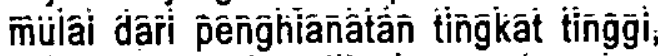

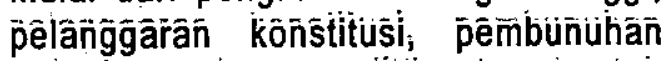

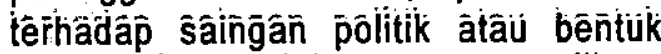

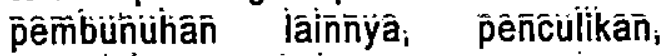

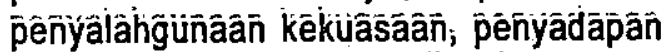

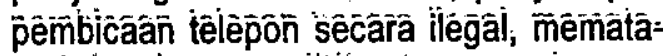
mâtăi saainḡâñ pólitík âtâu peenāhânãñ

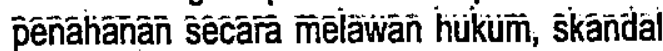

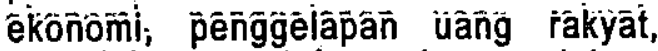

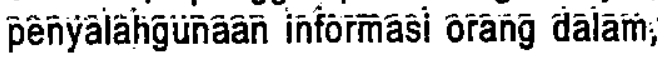

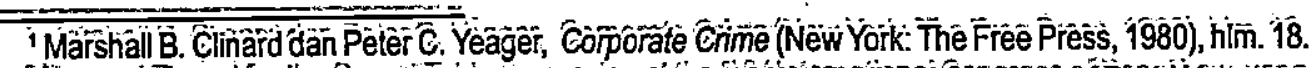

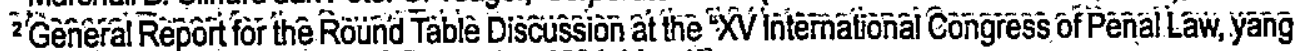

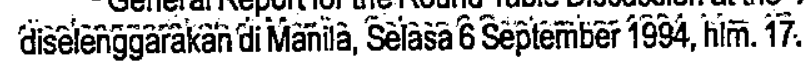


penyuapan, dan lain-lain. ${ }^{2}$ Sedangkan kejahatan korporasi yang merupakan bagian daniwhite-collar crime, tetapi tidak seperti whitecollar crime yang sering melibatkan individu atau kelompok kecil dari para individu melakukan kejahatan dalam lingkup profesi mereka atau kapasitas pekerjaan mereka. Kejahatan korporasi merupakan kejahatan organisasi yang terjadi dalam konteks saling keterkaitan yang sangat kompleks. Singkatnya, untuk dapat disebut sebagai kejahatan korporasi, apabila kejahatan tersebut dilakukan untuk kepentingan korporasi.

Timbulnya kejahatan korporasi tidak dapat dilepaskan dari pertumbuhan korporasi itu sendiri. Pada abad pertengahan keberadaan korporasi besar hanya sebagai sarana pengaturan pekerjaan dan pembentukan badan hukum (legal entity) kelompok para individu, seperti serikat sekerja, perkumpulan gereja, universitas, atau wilayah. Meskipun korporasi berstatus sebagai kelompok, tetapi raja mengizinkan mereka mempunyai kekuasaan legislatif dan pengadilan sendiri. Pada waktu itu, peranan korporasi lebih ditekankan pada kerjasama (asosiasi) daripada tujuan pemanfaatan penyediaan modal séperti korporasi pada umumnya.

'Munculnya' revolusi industri (1750-1850), semakin mendorong berkembangnya korporasi sebagai badan hukum dan badan ekonomi (legal and economic entity). Keadaan tersebutlah yang barangkali dapat dipandang sebagai pelopor atau perintis korporasi bisnis modem, yäitu dengan berdirinya British jointstock company dan Dutch East India Company. Mengenai yang terakhir ini, lebih dikenal dengan De Vereenigde Oost-Indische Compagnie (VOC) yang didirikan oleh Belanda pada 1602 dianggap sebagai korporasi pertama yang dibangun dengan modal (saham) yang permanen: Lebih dari tiga abad dasar dan ciri-ciri hukum korporasi dikembangkan sebagai badan yang diakuj secara resmi oleh negara, yang memiliki harta kekayaan untuk tujuan bersama, memiliki hak unituk menuntut dan dituntut secara bersamasama (share responsibility), dan keberadaannya yang melampaui masa hidup para anggotanya. Faktor-faktor tersebut integral dengan korporasi dewasa ini, dan dengan melakukan kegiatan ekonomi seperti seorang anggota korporasi selän mengurangi risiko terhadap mereka sendiri selaku individuindividu, juga sejumlah modal individu diperlukan untuk kegiatan korporasi. Dengan begitu; maka korporasi menjadi șebuah lembaga hukum yang dapat melakukan pengumpulan modal sebanyak mungkin melampaui periode waktu yang tidak dipengaruhi oleh kematian atau penarikan kembali dari pemilik modal.

Selanjutnya, pertumbuhan korporasi di awal abad ke XX, di mana pada 1909; di Amerika Serikat hanya ada dua perusahaan industri (industrial corporation), yaitu United States Steel dan Standard Oil of New Jersey yang sekarang berganti nama menjadi Exxon, memiliki aset melampaui $\$ 500$ juta setara dengan $\$ 2$ milyar. Tahun .1971, dua korporasi térbesar . tersebut hasil, penjualannya mendekati $\$ 47$ milyar, "kira-kira sama dengan dalam dollar tetap untuk penjualan lebih dari 200.000 perusahaan industri tahun 1899. Masih dalam abad ini telah terjadi pertumbuhan korporasi multinasional raksasa yang begitu cepat yang dapat memperkerjakan berpuluh-puluh tenaga kerja, sangat mempengaruhi pilihan konsumen, dan mendominasi segmen-segmen ekonomi 
dunia melalui operasi global mereka. Banyaknya jumlah sumber modal korporasi-korporasi besar tersebut, memungkinkannya untuk memakai dan merubah teknologi dalam skala besar. Dalam pada itu, sumbangan mereka yang sangat besar terhadap pembangunan industri dan perdagangan Amerika Serikat dan dunia barat, seperti halnya terhadap bangsa-bangsa yang sedang membangun. Karena tujuan dari korporasi modern diarahkan pada tercapainya tujuan pertumbuhan dan keuntungan, memiliki struktur hirarki yang kompleks, dan permainan pimpinan dari para pemegang saham sebagai peran kunci dalam pelaksanaannya. Dalam kaitan ini Miller sebagaimana dikutif oleh Clinard dan Yeager menyatakan, ${ }^{3}$ korporasi adalah a sociological organization and a political instrument, an economic force and a judicial person. Demikian juga dengan Drucker yang menjelaskan pentingnya ciri-ciri struktur yang dimulai oleh General Motors Corporation di tahun 1920-an yang telah banyak diikuti oleh industri. Adapun ciri-ciri tersebut meliputi desentralisasi kewenangan ke dalam bagianbagian yang mandiri (otonom) dan setiap usaha merupakan tanggungjawabnya sendiri, tanggungjawab penuh pimpinan divisi bagi keberhasilan divisinya, dan kontrol kebijakan top manajemen terhadap penggunaan dana dan promosi tingkat atas. Struktur organisasi suatu korporasi besar berdasarkan pada hubungan antara sejumlah besar orang-orang, yaitu pekerja, pengawas kelompok eksekutif, staf korporasi, dan dewan direktur dengan ketua dan wakil ketua, dan pada saat yang sama hubungan pejabat korporasi dengan anak perusahaannya.

Melihat pertumbuhan korporasi yang pesat itu, maka bagaimana dengan di Indonesia. Pada dasawarsa terakhir ini, bukan saja jumlahnya yang semakin meningkat melainkan munculnya korporasi-korporasi raksasa (giant corporations), karena disertai dengan meningkatnya diversifikasi di bidang usaha oleh perusahaan--perusahaan raksasa tersebut melalui usaha bersama di antara perusahaan-perusahaan domestik maupun perusahaan--perusahaan luar negeri, telah mendorong meningkatnya korporasi multinasional dan korporasi transnasional.

Dewasa ini bagian terbesar dari korporasi adalah konglomerat yang memimpin berbagai bidang industri. ${ }^{4}$ Dalam pada itu, Sofyan Mukhtar menulis, ${ }^{5}$ bahwa kehadiran konglomerat dalam pertumbuhan dunia usaha Indonesia akhir-akhir ini menjadi pembicaraan hangat setelah deregulasi diujung tahun 80-an dan awal tahun 90-an, sehingga perkataan konglomerat itu telah menjadi mode. Di Amerika Serikat, yang dikutifnya dari tulisan Harold Geneen, perkataan konglomerat itu menjadi mode pada penghujung 60 -an dan diawal 70 -an. Inti dari konglomerat, adalah akuisisi, konsolidasi atau fusi, dan merger. Karena itu, sebuah konglomerat adalah sebuah perusahaan yang melahap atau memakan perusahaan-perusahaan lain dengan tidak pernah kenyang-kenyangnya, sekalipun perusahaan-

${ }^{3}$ Marshal B. Clinard dan Peter C. Yeager, Corporate Crime (New York: The Free Press, 1980), hlm. 24.

‘Susanto, Kejahatan Korporas (Semarang: Penerbit UNDIP, 1995), hlm. 18-19.

${ }^{5}$ Majalah Forum Keadilan No. 26, Desember 1990, hlm. 50. 
perusahaan itu tidak saling berkaitan satu sama lainnya. Misalnya, perusahäán, sepatu, bank, perusahaan kayu, garmen, atau apa saja bersatu dalam sebuah rumah di bawah satu átap korporasi.

Dengan ditetapkannya " prọgám industrialisasi öleh . pemerintah padá Pembangunan Lima Tahun Ketujuh semasa pemerintahan' Orde Baru, ${ }^{6}$ di mana pada bagian Prioritas Pembangunan Lima Tahun Ketujuh dikemukakan: "Penataan dan pemantapan industri nasional yang mengarah pada pertuasan, penguatan, dan pendalaman struktur industri näsional yang makin kukuh dengan penyebarannya ke seluruh wilayah Indonesia sesuai dengan potensi daerah". Lebih lanjut, pada bagian Sàsarañ Bidang Pembangunan Lima Tahun Ketujuh dikemukakan: "Makin dinamis dan mantapnya perekonomian sebagai bagian integral dari pembangunan nasional, ditandai oleh berkembangnya peran pasar yang terkelola, berlanjutnya perluasan, penguatan, dan pendalaman struktur industri; ....". Demikian juga halnya apabila memperhatikan isi pidato Presiden Megawati Soekarnoputri yang disampaikan dalam Forum Bisnis Kerjasama Selatan-Selatan di Kuala Lumpur; Malaysia, pada hari Minggu 23 Februari 2003, bahwa: "Dengan kemampuan dan sumberdaya yang terbatas, dan selama ini hampir selalu terkuras untuk menyelesaikan persoalan politik dan keamanan di dálam negeri, maka sangat sulit bagi pemerintah negara berkembang mana pun untuk - dapat efektif menangani pembangunan kehidupan sejạhtera yang dicita-citakan. Saatnya pemerintah mengurangi perannya dan mendorong dunia usahauntuk melakukannya", hal ini sudah dapat diperkirakan adanya percepatan perkembangan korporasi dan sekaligus maraknya kejahatan korporasi di. Indonesia.

Kejahatan korporasi dalam kenyataannya dapat juga merambah ke dalam bidang politik, yaitú seperti sumbangan dana kampanye pemilihan umum dengan tujuan untuk menikmati fasilitas birokrasi demi untuk keuntungan ekoriomi. Hubungan antara penyumbang dan yang disumbang akan dilakukan secara tidak transparan, yaitu apabila' hal 'itu ada maksud untuk mengakali ketentuan Undang-undang. Beberapa kasus penyuapan-penyuapan oleh korporasi terhadap partai seperti yang terjadi di Amerika Serikat menunjukkan adanya keterlibatan korporasi dalam upaya untuk menjalin hubungan yang saling menguntungkan antara penyumbang dan yang disumbang. Memang abagamana yang diulis oleh Reksodiputo" bahwa dalam suatu negara dengan ekoniomi pasar bebas, maka sulit akan dihindari adanya jalinan antara kuasa ekonomi dengan kuasa pemerintahan (elit politik, pen). Kendati begitu, yang harus dapat dicegah adalah hubungan yang bersifat persekongkolan untuk kepentingan kelompok elit masing-masing:

6 Tap MPR No. II/MPR/1998 tentang Garis-garis Besar. Haluan Negara.

${ }^{7}$ Presiden Sóekarnoputri, Saatnya Pemerintah Mengurangi Perannya, Kompas Cyber Media, http:/l unwikompas.com, diakses tanggal 25 Februari 2003.

- " Mardjono Reksodiputro, "Kejahatan Terorganisasi dan Kejahatan oleh Organisasi", dalam Jümal Polisi Indonesia, Tahun:2, April 2000-September 2000, hlm. 45. 
Pertanyaannya, apakah Pemilu 2004 dengan sarana Undang-undang No. 12 Tahun 2003 tentang Pemilu Anggota DPR, DPD, dan DPRD akan dapat menjamin partai-partai politik bermain jujur dalam perolehan dana dalam rangka menyemarakkan Pesta Demokrasi?

\section{Kejahatan Korporasi.}

Ketika Sutherland memulai studinya mengenai pelanggaran hukum yang dilakukan oleh pelaku bisnis, dan studi itu sendiri dimaksudkan untuk membuktikan penjelasan umum mengenai perilaku kriminal. Teori-teori tentang kejahatan yang ketika itu masih menekankan pada penyakit sosial dan gangguan mental sebagài penyebab terjadinya kejahatan, khususnya kemiskinan dan keadaan sosial yang berkaitan dengan kemiskinan, seperti rumah yang tidak layak huni, kurangnya sarana rekreasi, telah dibantah oleh Sutherland. Sutherland yang ketika itu melakukan kajian terhadap kejahatan bisnis (business crimes), mengemukakan bahwa perilaku kriminal itu dipelajari, karena itu Sutherland yakin dengan teorinya itu untuk menerangkan kejahatan yang dilakukan oleh para pelaku bisnis. Mereka itu menurut Sutherland bukanlah orang-orang miskin atau pun kekurangan fasilitas rekreasi, akan tetapi dalam kenyataannya mereḱa. melakukan kejahatan. ${ }^{9}$.
Sehubungan dengan uraian di atas, sebenarnya pada 1907 Edwand Alswiwonth Ross $^{10}$ telah membuat sebuah tulisan yang dimuat dalam The Atlantic Monthly dengan menyebut para corporate executive yang melakukan kejahatan (corporate crime) sebagai criminaloid, yaitu orang (the perpetrator) yang menikmati kekebalan atas dosadosa. Menurutnya, kata kunci dari criminaloid is not evil impulse, tetapi moral insensibility. Criminaloid lebih suka mengorbankan kepentingan umum, dan apabila didakwa maka seolah-olah tidak bersalah dengan mengeluarkan dana untuk memperbaiki reputasinya. Contoh dari criminaloids corporate executives sebagaimana dikemukakan oleh Green, adalah dishonest bank inspectors, food adulterators (pemalsuan makanan, misalnya susu dicampuri air, pen.), corrupt judges, bribery and kickback schemes.

Apabila mundur sejenak ke belakang, bahwa apa yang sekarang disebut dengan kejahatan korporasi, demikian ditulis oleh Green, bukanlah suatu fenomena baru. Karena, lebih dari tiga ribu tahun yang lalu. seorang raja di Mesir yang bernama Horembeb telah melarang adanya korupsi dan kepada pelakunya diancam dengan pidana mati." Praktik korupsi semacam itu, dewasa ini telah berkembang ke berbagai bidang kehidupan manusia. Seperti mengganti. kualitas bahan bangunan yang tidak sesuai dengan rencana (bestek), penyuapan tingkat

${ }^{9}$ Sutherladn, "Crime of Corporation", dalam Geis dan Meier, White-Collar Crime (New York: The Free Press, 1977), hlm. 71-72.

${ }^{10}$ Ross, "The Criminaloid", dalam Gilbert Geis \& Robert F. Meier (ED), White-Collar Crime (New York: The Free Press, 1977), hlm. 31, 30; Sahetapy, Kejahatan Korporasi (Bandung: Ersco, 1994), hlm.13.

"Sahetapy, Kejahatan Korporasi (Bandung: Ersco, 1994), hlm. 4. 
tingigi (high level bribery), baik tataran nasional maupun internasional, dan sebagainya.

Kaitannya dengan penyuapan tingkat tinggi pada tataran intemasional ini, OECD ${ }^{12}$ pada dokumen tentang Revised Recommendation of the Council on Combating Bribery in International Business Transactions, yang diadopsi oleh Dewan Organisasi Kerjasama Ekonomi dan Pembangunan pada tanggal 23 Mei 1997, di mana pada bagian Criminalisation of Bribery of Foreign Public Officials, pada intinya merekomendasikan kepada negara-negara anggota untuk mengkriminalisasikan penyuapan terhadap pejabat publik asing yang berkaitan dengan transaksi bisnis internasional:

Meskipun kejahatan korporasi sudah melanda ke berbagai penjuru dunia, akan tetapi sebagaimana yang ditulis oleh Steven Box ${ }^{13}$ bahwa'ketika ia melakukan studi tentang pandangan masyarakat terhadap dampak dari kejahatan korporasi, akhirnya sampai pada kata kunci, yang ia sebut sebagai collective ignorance, bahwa mayoritas dari mereka yang diwawancarai temyāta tidak tahu terhadap kerugian yang diakibatkan oleh kejahatan korporasi. Namun, di antara mereka yang memang sedikit mengetahuinya, hanya beberapa orang saja yang dapat menentukannya secara tepat.

Ini berarti, masih banyak anggota masyarakat yang belum mengetahui atau menyadari bahwa kejahatan yang sebenamya itu justru yang dilakukan oleh korporasi. Di Amerika' Serikat sendiri yang pertumbuhan korporasinya begitu pesat, baru mengetahui sekitar tahun 70-an. Hal itu terbukti ketika pada 1967 Lou Harris menanyakan kepada rakyat Amerika, siapa yang mereka pandang sebagai berbahaya dan merugikan negara, yang dijawab bahwa kelompok yang mernbahayakan itu adalah para homoseksual, pelacur, para ateis, dan mereka yang menentang perang. Tujuh tahun kemudian, pertanyaan yang sama diajukan, ternyata memperoleh jawaban yang sama sekali berbeda. Pertanyaan yang diajukanbertepatan dengan terbóngkarnya skandal watergate yang melibatkan Presiden Richard Nixon dalam pemilihan presiden 1970 dan pada 1974 ia mengundurkan diri dari jabatan presiden. Mereka yang dipandang berbahaya, dan merugikan negara adalah orang yang menyewa mata-mata politik (political spies); serangan bom rahasia, politisi yang menggunakan alat elektronik untuk mematamatai lawan, pelaku bisnis yang memberikan sumbangan politik secara ilegal, dan politisi yang menggunakan jasa $\mathrm{Cl} A$ dan $\mathrm{FBI}$ (bandingkan dengan kasus konspirasi dalam upaya menjatuhkan Presiden Clinton, yaitu dengan memanfaatkan Monica Lewinsky, seorang wanita magang di Gedung Putih), serta gerakan rahasia lainnya untuk tujuan politik atau mencoba membatasi kebebasan.

${ }^{12}$ Organisation for Economic Co-operation and Development, Convention on Combating Bribery of Foreign Public Officials in International Business Transactions, 1998, hlm. 20.

${ }^{13}$ Steven Box, "Power, Crime and Mystification", Tavistock Publications, dalam Frank Parkin (General Editor), Tavistock Studies in Sociology (London and New York: 1983), hlm. 16. The one indisputable fact these studies revealed is that the majonity of those interviewed were not familiar with the extent of, or damage caused by corporate crime and amongst the knowledgeable minoritu, few were able to define it with any precision. 
Salah satu dari mereka yang dipandang merugikan negara tersebut, adalah keterlibatan korporasi menyumbang dana kampanye pemilihan Nixon. Menurut Clinard dan Yeager, ${ }^{14}$ bahwa sumbangan korporasi untuk kampanye pemilihan di negara bagian dan federal sudah berlangsung lama dan merupakan praktik kotor dan merusak proses demokrasi. Karena itu, sejak 1971 korporasi dilarang menyumbang dana kampanye kepada calon presiden. Lebih .lanjut dikemukakan, bahwa sumbangan tersebut pada umumnya adalah untuk tujuan ekonomi, yaitu untuk menikmati jaminan birokrasi dan mempengaruhi putusan politik, sehingga akan memberikan pada peningkatan keuntungan kọrporasi yang lebih tinggi. Salah satu sumbangan korporasi yang terbesar untuk Nixon, berasal dan perusahaan-perusahaan minyak. Berdasarkan laporan yang dibuat oleh anggota Congres, Aspin dan stafnya pada 1974; bahwa pejabat-pejabat perusahaan minyak, pemegang saham mayoritas, dan -lima bersaudara Rockefeller yang memiliki $1 \%$ saharn Exxon menyumbang US $\$ 5.250 .540$. Selanjutnya, tiga perusahnaan minyak, yaitu Gulf, Phillips, dan Ashland total sumbangan US $\$ 300.000$ (sumbangan ini kernudian dikembalikan). Penyumbang utama, adalah para pejabat Gulf Oil dengan total US $\$ 1.176 .500$. Terhadap sumbangansumbangan tersebut, Aspin șecara terperinci rnenyebutkan: Gulf Oil jumlah sumbangan US\$1.176.500; Getty Oil, US\$179:292; Standard Oil of California, US\$166.000; Sun Oil,
US\$157.798; Phillips Petroleum, US\$137.000; Exxon, US\$127.747; dan Ashland Oil, US $\$ 103.500$.

Selain itu, Senator Bob Dole yang bersaing dengan Bill Clinton untuk merebut tiket ke Gedung Putih, dituduh menggunakan dana ilegal. Tuduhan tersebut dilontarkan oleh kelompok independen pengamat pemilihan presiden dari harian The Kansas City Star yang terbit di Kansas City. Sumbangan ilegal yang diterima Dole berasal dari perusahaan alat olahraga di Massachusetts dan perusahaan Aqua Leisure Industries yang masing-masing bejumlah (USD 36.000 dan USD 1.000). Pada 1994 sebuah perusahaan gas di Oklahoma menyumbang sebesar USD 150.000 kepada kandidat dari Partai Demokrat, Stuart Price yang bersaing dengan kandidat dari Partai Republik, Steve Largent, ketika berlangsung kampanye untuk menjadi anggota Kongres. ${ }^{15}$ Selanjutnya, pada tanggal 7, 8, dan 9 Oktober 1996, tiga media massa terkenal Amerika. Serikat (The New York Time, Wall Street Journal, dan Washington Post) telah mengungkap, bahwa 1992 salah seorang konglomerat lndonesia, James Riady dari Lippo Group, menyumbang dana sebesar USD 175.000 untuk kepentingan kampanye Clinton. Karena itu pada tanggal 11 Oktober 1996, Senator John McCain meminta Departemen Kehakiman mengusut kasus ini, ${ }^{16}$ yang kemudian diikuti oleh Dole dan dijadikannya sebagai menu untuk menarik opini publik guna melumpuhkan Clinton.

Meskipun Undang-undang Pemilu di

\footnotetext{
${ }^{14}$ Marshal B. Clinard dan Peter C. Yeager, Corporate Crime (New York: The Fress Press, 1980), hilm. 157.

${ }^{15}$ Harian Jawa Pos, 9 Mei 1996, hlm. 2.

${ }^{16}$ Harian Jawa Pos, 15 Oktober 1996, him.1.
} 
Amerika Serikat telah melarang perusahaan memberikan sumbangan dana kampanye atau menggunakan nama karyawannya sebagai penyumbang, akan tetapi pada tahuntahun berikutnya praktek semacam itu masih terus berlangsung. Mengenai hal ini.telah diungkapkan oleh Corporate Crime Reporter pada tanggal 3 Juli 2003 dengan judul, Dirty Money: Corporate.Criminal Donations to the two Major Panties ${ }^{17}$ Dalam laporan ini dikemukakan bahwa partai politik seharusnya tidak - menerima' uang dari narapidana (korporasi jahat), tahun lalu ketika skandal WorldCom, ImClone, dan Enron sedang merebak, para politikus dari kedua partaj politik (Republik dan Demokrat) dibawah pengawasan yang ketat dari pers: agar mengembalikan sumbangan kepada perusahan-perusahan penyumbang. Namun, kedua partai besar itu secara rutin menerima jutaan dollar dari korporasi jahat. Selanjutnya, dilaporkan bahwa terdapat lebih dari 31 korporasi jahat menyumbang $\$ 9.3$ juta kepada partai Demokrat dan Republik selama putaran pemilu-2002. Sumbangan yang diterima oleh partai Republik berjumlah $\$ 7.2$ juta $(77 \%)$ dan $\$ 2.1$ juta kepada Demokrat (23\%): Lima di antaranya merupakan penyumbang terbesar terhadap kedua partai tersebut adalah: Archer Daniels Midland ( $\$ 1.7$ juta); Pfizer ( $\$ 1.1$ juta); Chevron $(\$ 87.5,400)$; Northrop. Grumman $(\$ 741,250)$; dan American Airlines $(\$ 655,593)$.

Selain itu, Enron juga termasuk dalam daftar penyumbang dana politik dalam penggalangan dana kampanye George W. Bush. Akibat hubungan yang demikian itu, banyak orang yang mencurigai pemerintahan Bush dan para politisi telah dan akan memberikan perlakuan istimewa dalam bisnis Enron selama ini. Memang dari serangkaian skandal ini, belakangan diketahui bahwa banyak sekali pejabat tinggi gedung putih dan politisi di Senat Amerika Serikat yang pernah menerima kucuran dana politik dari Enron. Tercatat $70 \%$ senator, baik dari partai Republik maupun partai Demokrat pernah menerima dana politik. ${ }^{18}$

Amerika Serikat dalam upaya untuk mencegah terjadinya penyuapan-penyuapan politik, maka dibentuk the Federal Election Campaign Act of 1971 sebagaimana yang sudah diubah dan ditambah dengan undangundang yang disebut dengan Bipartisan Campaign Reform Act of 2002. Di Indonesia dalam menghadapi Pemilu tahun 2004 telah mengantisipasi terjadinya praktek-praktek yang tidak terpuji itu dengan Undang-undang No. 12 Tahun 2003 tentang Pemilihan Umum, Anggota Dewan Perwakilan Rakyat, Dewan Perwakilan Daerah, dan Dewan Perwakilan Rakyat Daerah (Lembaran Negara Tahun 2003 Nomor 37) tanggal 11. Maret 2003. Dalam Bab VIII Bagian Kedua yang menyangkut Dana Kampanye Pemilihan Umum telah diatur dalam Pasal 78, 79, dan 80.

Pasal 78 misalnya menentukan, bahwa dana kampanye Pemilu dapat diperoleh peserta Pemilu dari anggota Partai Politik Peserta Pemilu yang bersangkutan termasuk

${ }^{17} \mathrm{http}: / /$ www.corporatecrimereporter.com/ccrreport.pd

${ }^{18}$ Sudirman Said, Ketua Badan Pelaksana Masyarakat Transparansi Indonesia (MTI); "Belajar dari Skandal Enron", dalam harian Tempo, Selasa, 5. Pebruari 2002. 
calon anggota DPR, DPD, DPRD Provinsi, dan DPRD Kabupaten/Kota; pihak-pihak lain yang tidak mengikat yang meliputi badan hukum swasta, atau perseorangan, baik yang disampaikan Partai Politik peserta Pemilu maupun kepada calon anggota DPR, DPD, DPRD Provinsi, dan DPRD Kabupaten/Kota. Sumbangan yang diperoleh dari perseorangan tidak boleh melebihi $\mathrm{Rp} 100.000 .000,00$ (seratus juta rupiah) dan dari badan hukum swasta tidak boleh melebihi Rp 750:000.000,00 (tujuh ratus lima puluh juta rupiah).

Dengan adanya undang-undang tersebut, diharapkan akan dapat mencegah atau minimal memperkecil terjadi pelanggaranpelanggaran dalam melaksanakan kampanye. Akan tetapi yang patut dipertanyakan, apakah dengan adanya undang-undang dimaksud akan dapat menjamin bahwa para pihak (partai) yang berkampanye akan bersih dari permainan-permainan yang mengakali undang-undang, dalam arti berkolusi dengan suatu korporasi, khususnya dalam hal transfer dana. Pertanyaan demikian memang patut dikemukakan, karena apabila memperhatikan rumusan P.asal 138 ayat (5) Undang-undang No. 12 Tahun 2003 yang menyebutkan bahwa, baik yang memberi maupun yang menerima dana kampanye melebihi ketentuan sebagaimana yang diatur dalam Pasal 78 diancam dengan pidana penjara paling singkat 4 (empat) bulan dan paling lama 24 (dua puluh empat) bulan dan/atau denda paling sedikit $R p 200.000 .000,00$ (dua ratus juta rupiah) atau paling banyak Rp 1.000:000.000,00 (satu milyar rupiah). Ancaman pidana yang terdiri dari pidana penjara dan denda itu menunjukkan, bahwa pembentuk undangundang lebih mengandalkan pidana pokok dalam upaya penanggulangan kejahatan yang berkaitan dengan sumbangan dana kampanye tersebut.

- Padahal apabila sasaran yang hendak dituju' adalah korporasi (penyumbang.dana) atau pun partai politik (penerima sumbangan), maka sanksi berupa pidana denda (pidana pokok) tidaklah cukup efektif untuk mencegah korporasi melakukan kejahatan. Karena itu, perlu ditunjang dengan ketentuan pidana tambahan. Dalam hubungan ini Balakrishnan menulis ${ }^{19}$ bahwa penerapan pidana denda terhadap perusahaan atau korporasi (termasuk partai politik), masih belum cukup. Karena, sanksi yang berupa pidana denda tidak akan pernah dirasakan sebagai hukuman. Anggapan bahwa denda sebagai hukuman hanyalah di atas kertas. Untuk itu, perlu ada ketentuan khusus, seperti menghentikan kegiatan korporasi untuk sementara waktu dan untuk mengelola korporasi itu dilakukan oleh negara.

Dengan adanya rumusan sebagaimana terimplementasi dalam Pasal 138 ayat (5) di atas, masih diragukan keefektifan Undangundang No. 12 Tahun 2003 untuk mencegah mengalimya dana sumbangan yang melebihi ketentuan untuk kepentingan kampanye Pemilu. Akibat lebih lanjut; hubungan antara pemberi dan penerima akan semakin harmonis, sebab bukankah sumbangan-sumbangan itu pada umumnya adalah untuk tujuan ekonomi,

19. Balakrishnan, "Reform of Criminal in India Some Aspects", dalam Resource Material Series No. 6, UNAFEl, Fuchu, Tokyo, Japan, Oktober 1973, hlm. 48. 
yaitu untuk menikmati jaminan birokrasi dan mempengaruhi putusan politik, sehingga akan memberikan pada peningkatan keuntungan korporasi yang lebih besar, dan dilakukan secara rahasia.

Sampai sejauh mana hubungan itu berlangsung? Dalam kaitan ini, Dionysios Spinellis dalam bagian tulisannya mengenai Top hat criminality and white collar crime, ${ }^{20}$ membedakan dua bentuk kejahatan ini. Pada white-collar criminals (corporate criminal, pen), umumnya berkaitan dengan kegiatan bisnis utamanya dalam sektor swasta, sedangkan top hat criminals berkaitan dengan pejabat publik yang memegang dan menggunakan kewenangan politik. Apa yang dilakukan oleh white-collar criminals, sifatnya tidak langsung dan bergantung pada sejauhmana posisi keuangan dan pengaruh mereka terhadap orang yang memegang kekuasaan tersebut. Sedangkan pada pejabat publik, sifatnya langsung, karena berkaitan dengan kedudukan politis yang melekat padanya.

\section{Simpulan ,}

Dalam kalimat "..... yang menerima dana kampanye ....." dalam Pasal 138 ayat (5) tidak ada keterangan atau penjelasan. lebih lanjut yang menyebutkan bahwa pengertian yang merima itu adalah partai politik. Kekaburan ini akan dapat dijadikan alasan oleh pihak yang berkepentingan untuk menghindari tuntutan pidana dengan alasan bahwa dalám undangundang tidak ada ketentuan, yang menyebutkan bahwa pengertian yang menerima itu adalah sama dengan partai politik. Di samping itu, apabila mencermati rumusan sánksi pidana di atas, maka tidak ada satu pasalpun yang menyebutkan, misalnya jika partai politik menerima sumbangan dana kampanye Pemilu melebihi dari yang ditentukan akan dijatuhi pidana berupa tidak diikutkan dalam Pemilu atau yang lebih berat pembubaran partai. Demikian juga dengan korporasi penyumbang dana, selain dijatuhi pidana denda, juga misalnya dikenai pidana berupa pembubaran usaha, didiskualifikasi dari kontrak-kontrak pemerintah, pemecatan manajer, memberitahukan kepada publik di semua negara tempat beroperasinya korporasi tersebut mengenai sanksi yang dikenakan kepadanya.

Dengan demikian, dilihat dari aspek politik hukum pidana, hal itu merupakan kelemahan pembentuk undang-undang dalam mengantisipasi kemungkinan partai politik melakukan perbuatan curang dalam perolehan dana kampanye Pemilu, serta upaya mencegah korporasi memberikan sumbangan yang melampaui jumlah yang ditetapkan oleh Undang-undang. Apabila sumbangan-sumbangan itu dilakukan secara sembunyi-sembunyi, jelas akan mengaburkan

${ }^{20}$ Dionysios Spinellis, "Crime of Politicians in Office (or Top hat crimes)", Materi Penataran Nasional Hukum Pidana dan Kriminologi, di sampaikan oleh Barda Nawawi Arief, di Hotel Grasia, Semarang, 23-30 Nopember 1998, hlm. 23. The white collar criminals in general are making business or exercise professions mainly in the private sector, the politicians are holding public offices and using political power. The power of the white collar criminals is indirect; it is based on their financial position and their influence with the persons in power. The power of the politicians direct; they exercise it. 
makna demokrasi yang mensyaratkan adanya keterbukaan. Padahal, diadakannya Pemilu merupakan perwujudan dari PESTA DEMOKRASI yang sangat ditinggikan itu. Semoga, yang dikhawatirkan ini tidak akan terjadi. Suatu hal yang perlu ditegaskan, bahwa adanya undang-undang bukan untuk dilanggar, melainkan untuk dipatuhi, sehingga kemenangan yang diperoleh dalam Pemilu bukan karena melalui jalan yang tidak halal. Demikian juga dengan korporasi, keuntungan ekonomi yang akan diraih bukan karena hasil kolusi, melainkan hasil dari usaha yang wajar.

\section{Daftar Pustaka}

Balakrishnan, "Reform of Criminal in India Some Aspects", dalam Resource Material Series No. 6, UNAFEl, Fuchu, Tokyo, Japan, Oktober 1973.

Clinard, Marshal B. dan Peter C. Yeager, Corporate Crime, New York: The Free Press, 1980.

Clinard, Marshall B. dan Peter C. Yeager, Corporate Crime, New York: The Free Press, 1980.

Dionysios Spinellis, "Crime of Politicians in Office (or Top hat crimes)"; Materi Penataran Nasional Hukum Pidana dan Kriminologi, di sampaikan oleh Barda Nawawi Arief, di Hotel Grasia, Semarang, 23-30 Nopember 1998.

Geis dan Meier, White Collar Crime, New York: The Free Press, 1977.

Geis, Gilbert \& Robert F. Meier (ED), White-
Collar Crime, New York: The Free Press, 1977.

General Report for the Round Table Discussion at the "XV International Congress of Penal Law, yang diselenggarakan di Manila, Selasa 6. September 1994.

Organisation for Economic Cooperation and Development, Convention on Combating Bribery of Foreign Public Officials in International Business Transactions, 1998.

Parkin, Frank, (General Editor), Tavistock Studies in Sociology, London and New York: 1983.

Sahetapy, Kejahatan Korporasi, Bandung: Ersco, 1994.

Susanto, Kejahatan Korporas, Semarang: Penerbit UNDIP, 1995.

Tap MPR No.ll/MPR/1998 tentang Garis-garis Besar Haluan Negara.

http://www.corporatecrimereporter.com/ ccrreport.pd.

Harian Jawa Pos, 15 Oktober 1996.

Harian Jawa Pos, 9 Mei 1996.

Harian Tempo, Selasa, 5 Pebruari 2002.

Jurnal Polisi Indonesia, Tahụn: 2, April 2000September 2000, hlm. 45.

Kompas Cyber Media, http:/l uww.kompas.com, diakses tanggal 25 Februari 2003.

Majalah Forum Keadilan No. 26, Desember 1990. 